\title{
RYZYKO GEOTECHNICZNE W PROJEKTOWANIU I REALIZACJI GŁĘBOKICH WYKOPÓW
}

\author{
Tomasz Godlewski ${ }^{\bowtie}$, Monika Niemyjska \\ Instytut Techniki Budowlanej, Warszawa
}

\begin{abstract}
STRESZCZENIE
Normy europejskie (Eurokody) zakładają, że wdrażane są odpowiednie działania na każdym etapie procesu inwestycyjnego - od badań wstępnych, poprzez fazę projektu, wykonawstwa, aż po użytkowanie i obsługę obiektu. Głównym celem tych działań jest ograniczanie możliwych zagrożeń, w tym związanych ze zmiennością warunków w podłożu (georyzyko). Pierwszym krokiem jest poprawne rozpoznanie warunków geotechnicznych podłoża budowlanego. Artykuł ma na celu przypomnienie o losowej zmienności ośrodka gruntowego, wymagań związanych z poprawnym rozpoznaniem i badaniem podłoża według PN-EN 1997-2 jako elementy wyjściowe do projektowania geotechnicznego oraz o konsekwencjach wynikających z błędów w opisie analizowanego modelu budowy geologicznej. Szczególnie obiekty budownictwa podziemnego (tunele, obiekty realizowane w głębokich wykopach) są narażone na wszelkie georyzyka i wymagają większej uwagi oraz świadomości potrzeby ich identyfikacji. Na przykładzie realizacji głębokich wykopów w zróżnicowanych warunkach gruntowo-wodnych w artykule zostaną przedstawione aspekty związane z rolą dokładności rozpoznania geotechnicznego oraz tworzeniem wiarygodnego i użytecznego modelu podłoża, jako elementy pozwalające na identyfikację i minimalizację georyzyka, a także odpowiednie nim zarządzanie.
\end{abstract}

Słowa kluczowe: rozpoznanie podłoża, głęboki wykop, model podłoża, georyzyka, zarządzanie ryzykiem

\section{WSTĘP}

Poprawne i pełne rozpoznanie podłoża budowlanego jest podstawą ograniczenia ryzyka związanego z realizacją każdej inwestycji. W przypadku realizacji budowli podziemnych, w tym głębokich wykopów, jest to element kluczowy, decydujący często o sukcesie inwestycji, bez narażania się na dodatkowe koszty. W zakresie rozpoznawania i badania podłoża według Eurokodu 7 (PN-EN 1997-1 i 2:2008. Eurokod 7), w kontekście całego procesu inwestycyjnego, prawidłowo zidentyfikowany typ budowy geologicznej, opracowane parametry geotechniczne oraz kontrola jakości wykonania robót na budowie mają największe znaczenie dla spełnienia podstawowych wymagań projektu - często większe niż dokładność modeli oblicze- niowych czy wartości współczynników częściowych (Mitew-Czajewska, 2017). Jest to ważne i prawdziwe $\mathrm{z}$ punktu widzenia całego procesu projektowania, ponieważ badania podłoża to etap związany $\mathrm{z}$ pozyskiwaniem danych geotechnicznych do dalszych prac związanych $\mathrm{z}$ modelowaniem interakcji konstrukcji $\mathrm{z}$ gruntem. W tym celu niezbędne dla projektowania geotechnicznego jest przyjęcie wiarygodnego modelu i parametrów geotechnicznych podłoża. Wpływ ma na to między innymi: odpowiedni dobór metod badawczych, jakość zastosowanego sprzętu, poziom edukacji i staranności wykonania testu przez operatora, losowość mierzonych parametrów podczas badania, jakość próbek do badań kalibracyjnych w laboratorium. Częścią tego procesu poznawczego jest dobór odpowiedniej metody obliczeń związanej z rodzajem

$凶_{\text {t.godlewski@itb.pl }}$ 
zadania (konstrukcji). Rodzaj modelu determinuje parametry niezbędne do obliczeń, co warunkuje metody badań w celu ich określenia. W pracy Pottsa (2003), dotyczącej przewidywań odnośnie kierunku rozwoju zastosowania metod numerycznych w projektowaniu geotechnicznym, właściwie zwrócono również uwagę na problem rutynowego dokumentowania warunków podłoża, bez uwzględniania celu, któremu mają służyć parametry określone $\mathrm{w}$ ramach rozpoznania.

\section{ZGODNOŚĆ MODELI PODŁOŻA Z RZECZYWISTOŚCIA}

Proces związany $\mathrm{z}$ rozpoznaniem podłoża gruntowego, którego efektem finalnym mają być dane do projektowania (geotechnicznego), ma charakter analityczny i wieloetapowy. Przed rozpoczęciem etapu samych badań, w celu uniknięcia dodatkowych kosztów związanych np. $\mathrm{z}$ niewłaściwym doborem me- tod rozpoznania, warto jest skorzystać z dostępnych danych archiwalnych. Obecnie istniejące materiały kartograficzne czy archiwalne dokumentacje można stosunkowo łatwo pozyskać lub mieć praktycznie podgląd online (np. mapy geologiczne, otwory z banków danych, takich jak CBDG udostępnianych przez PIG-PIB). Niekiedy dużą wiedzę o możliwych problemach geotechnicznych mogą wnieść dane historyczne dotyczące przeszłości analizowanego terenu, np. charakteru użytkowania.

Należy wyraźnie podkreślić, że każdy przekrój (geologiczny, geologiczno-inżynierski czy geotechniczny) to zawsze tylko model, a nie dokładne odbicie rzeczywistości. Doskonale obrazuje to schemat (rys. 1) przedstawiony w pracy Kowalskiego (1988).

W zależności od etapu projektowania oraz zakresu i dokładności rozpoznania warunków gruntowo-wodnych otrzymuje się coraz dokładniejszy model budowy geologicznej. Według Kowalskiego (1998)

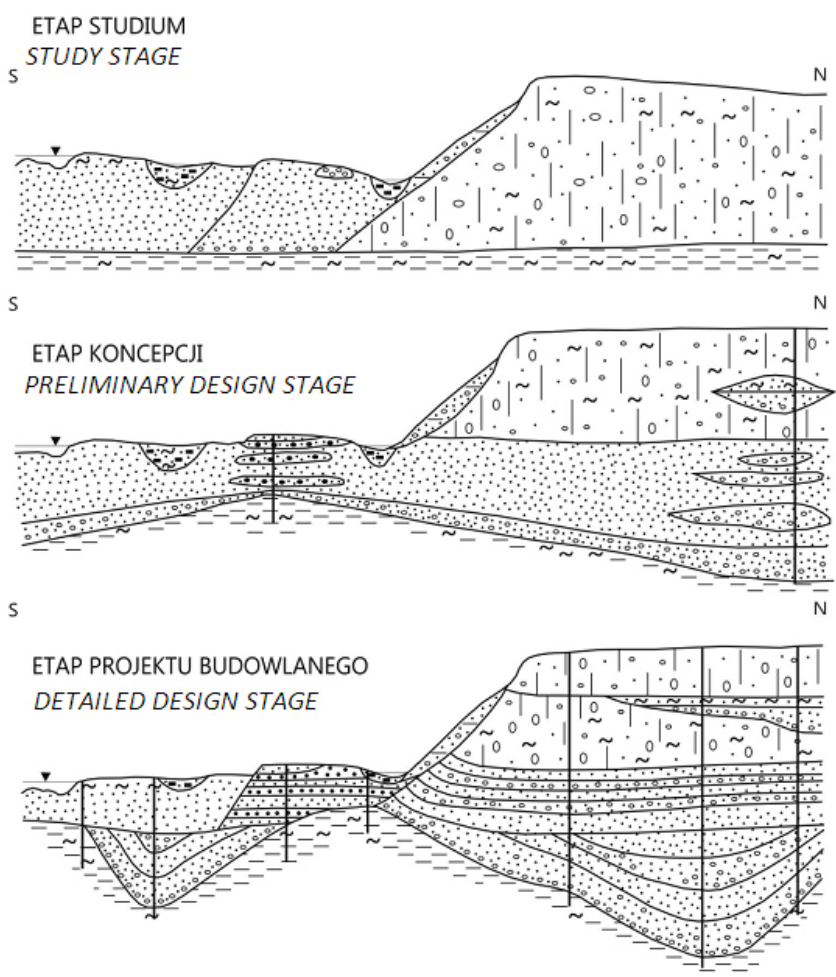

Rys. 1. Modele budowy geologicznej sporządzone dla różnych etapów projektowania i dokumentowania konkretnego obiektu inwestycyjnego (Kowalski, 1988)

Fig. 1. Geological structure models drawn up for different stages of design and investigation for a specific investment (Kowalski, 1988) 
termin model geologiczny rozpatrywany w sensie metodologicznym to realny (możliwy) model o umownym prawdopodobieństwie zgodności z rzeczywistością geologiczną definiowaną jako zbiór trudno dostępnych informacji, zjawisk i procesów oraz relacji między nimi. W praktyce nigdy nie jest możliwe osiagnięcie takiego zagęszczenia punktów dokumentacyjnych (de facto materialnych punktów obserwacji i pomiarów oraz profili gruntowych), aby nie tyle one same, ale chociażby ich otoczenia (obszar o dużym prawdopodobieństwie niezmienności) stykały się ze sobą (lepiej gdyby zachodziły na siebie). W typowych (rutynowych) rozstawach badań danego terenu pomiędzy kolejnymi punktami rozpoznania (wiercenia/sondowania) istnieje nieskończona liczba punktów materialnych, w których nie zostały dokonane jakiekolwiek obserwacje czy pomiary. Często zapominają o tym konstruktorzy, którzy sa przyzwyczajeni do materiałów wytwarzanych $\mathrm{w}$ warunkach kontrolowanych i oczekują opisu warunków i charakterystyki ośrodka wytworzonego przez naturę, niekiedy na podstawie pojedynczych otworów. Jeśli spojrzy się na ten problem statystycznie, to ilość danych z otworów i pobranych próbek w kontekście całej analizowanej objętości podłoża stanowi ułamek procenta.

Interpretacja danych pozyskanych na poszczególnych etapach rozpoznania to kolejne zagadnienie związane z ryzykiem geotechnicznym. O właściwościach podłoża $\mathrm{w}$ miejscach istnienia niezbadanej przestrzeni podłoża można wnioskować w sposób pośredni, stosując metody indukcji niezupełnej
(Kowalski, 1998). Konstruowanie takiego modelu polega na łączeniu liniami różnych punktów materialnych o przypisanych jednakowych wartościach, ustalonych w trakcie rozpoznania rzeczywistych warunków, w odpowiedniej skali, z wymaganą częstotliwością i dokładnością oraz stosowną metoda. Powstają w ten sposób granice obrazujące przyjęty układ budowy podłoża. Skoro pomiędzy dwoma punktami teoretycznie można wykreślić dowolną liczbę linii, to w aspekcie modelowania warunków gruntowych nawet przy zachowaniu najlepszej wiedzy możliwe jest uzyskanie co najmniej kilku równie prawdopodobnych obrazów starających się odzwierciedlić rzeczywistość. Doskonale obrazuje to schemat (rys. 2) przedstawiony w pracy Wysokińskiego (1995).

W praktyce granice między warstwami prowadzi się na zasadzie dowolnej interpolacji, łącząc punkty granic wydzieleń, niekiedy nawet automatycznie. Łatwo to sobie wyobrazić, analizując przypadek teoretyczny (rys. 2), w którym przy trzech wierceniach i trzech warstwach A, B, C możliwe jest kilkadziesiąt różnych interpretacji. W zależności od poziomu wiedzy i doświadczenia osoby dokumentującej podłoże istnieje wiele możliwości interpretacji takiego przekroju: od najprostszych wariantów (linia ciagła, grubsza) do przypadków bardziej złożonych - maksymalna miąższość warstwy B (kreskowanie pionowe); minimalna miąższość warstwy B (kratka). Widać tu wyraźnie, że w przypadku np. oceny położenia stropu poszukiwanej warstwy można wyciagnać różne wnioski tylko z powodu różnych możliwych wariantów przebiegu granic między profilami.

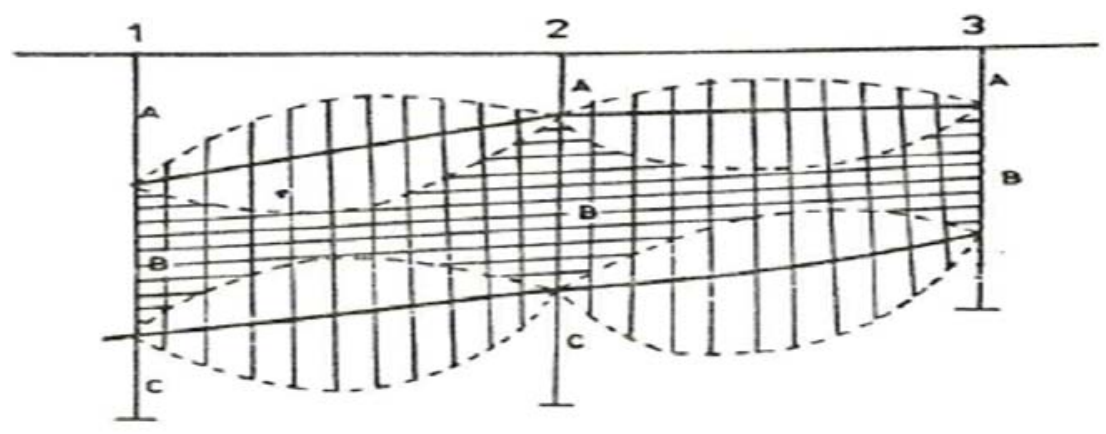

Rys. 2. Poglądowy przekrój z możliwą interpretacją przebiegu warstw - przykład z publikacji (Wysokiński, 1995)

Fig. 2. Overview cross section of the possible interpretation of the course of the layers - example from publication (Wysokinski, 1995) 
Teoretycznie na bazie tego samego zbioru danych można skonstruować wiele różnych modeli (matematycznych i graficznych) opisywanej przestrzeni podłoża gruntowego, o jednakowym stopniu (o jednakowej wartości umownego prawdopodobieństwa) ich zgodności z rzeczywistością. Aby uzyskać model o większym umownym prawdopodobieństwie (a więc bliższy rzeczywistości), dający podstawę do podejmowania słusznych decyzji inwestycyjnych, należy zwiększyć zbiór wiarygodnych danych (wykonanie dodatkowego rozpoznania). Zwiększenie liczby punktów dokumentacyjnych dotyczących danego terenu sprawia, że zmniejszają się możliwości racjonalnego konstruowania jednakowo wiarygodnych modeli podłoża, przybliżających do modelu idealnie zgodnego. Możliwość skonstruowania modeli w pełni zgodnych jest iluzoryczna z uwagi na ograniczenia metodologiczne, techniczne i ekonomiczne, a także czasowe. W praktyce istotne jest, aby podjęte działania skutkowały opracowaniem modelu o wartości prawdopodobieństwa zgodności z rzeczywistościa, pozwalającego na bezpieczne i racjonalne zaprojektowanie oraz realizację inwestycji. Opis budowy geologicznej czy ocena geotechnicznych warunków posadowienia wymagaja więc nie tylko wiedzy, ale i ogromnego doświadczenia.

Najczęstszym błędem, który na tym etapie rozpoznania podłoża można zaobserwować, jest zbyt automatyczne „trzymanie się” nazw gruntów i wydzielanie tylko na ich podstawie kolejnych warstw, nie licząc się z genezą gruntów i ich właściwościami.
Przy prowadzeniu granic na przekrojach ważne są również wiedza o procesach geologicznych powstania (geneza) poszczególnych rodzajów gruntu (np. dolinny układ piasków rzecznych, cykliczność sedymentacji, wcięcia erozyjne), a także zachowywanie i przestrzeganie następstwa warstw (zgodnie z kolejnością powstania). Najczęściej mamy do czynienia $\mathrm{z}$ najprostszym przebiegiem warstw, jednak należy pamiętać, że analizuje się ośrodek przyrodniczy, który potrafi zaskakiwać nawet najbardziej doświadczonych dokumentatorów. Na rysunku 3 jako przykład skrajny przedstawiono układ warstw (opis gruntów nie jest potrzebny, należy prześledzić zmienność samych szrafur) udokumentowany w przekopie Trasy Łazienkowskiej w Warszawie. Jest to rejon skarpy warszawskiej, gdzie utwory „iłów plioceńskich” są silnie zaburzone glacitektoniczne, z góry przykryte horyzontalnie utworami młodszymi (plejstoceńskie gliny zwałowe).

Zmienność przebiegu warstw na przestrzeni $10 \mathrm{~m}$ jest ogromna, stąd każda próba interpretacji przy nawet znacznej liczbie punktów dokumentacyjnych w takiej sytuacji jest obarczona dużą niepewnością. Przypadek ten pokazuje, jak ważne z punktu widzenia opisu podłoża i dalszych prac projektowych jest ostrożne i krytyczne niekiedy podejście do przedstawianego obrazu podłoża, a także konieczność korzystania z wiedzy i doświadczeń osób (geologów, geomorfologów, hydrogeologów, geotechników) przy ustalaniu modelu podłoża do dalszych prac projektowych (zwłaszcza w przypadku warunków skomplikowanych i obiektów III kategorii geotechnicznej).

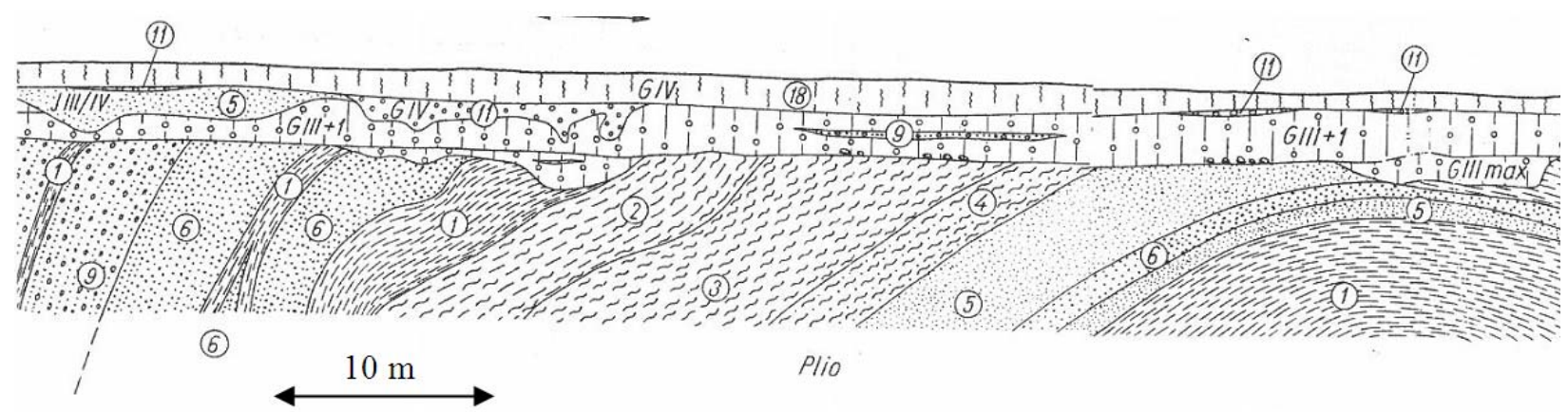

Rys. 3. Rzeczywisty obraz budowy podłoża - przekrój geologiczny wykartowany z przekopu wzdłuż Trasy Łazienkowskiej (Brykczyńska i Brykczyński, 1974)

Fig. 3. The real view of subsoil - the geologic cross-section taken along the Trasa Łazienkowska (Brykczyńska \& Brykczyński, 1974) 


\section{RYZYKO W PROJEKTOWANIU I REALIZACJI GŁĘBOKICH WYKOPÓW}

Budownictwo podziemne to dziedzina budownictwa, w której kluczowego znaczenia nabiera konieczność identyfikacji, analizy i zarządzania ryzykiem geotechnicznym. W tej branży ryzyko związane $\mathrm{z}$ warunkami geologicznymi, hydrogeologicznymi w kontekście geotechnicznych warunków posadowienia stanowia istotna, a w przypadku obiektów podziemnych dominującą składową ryzyka kontraktowego (Godlewski, 2016). Brak świadomości jego znaczenia i wagi, a także „uczciwego" i świadomego podziału możliwych georyzyk pomiędzy wszystkie zaangażowane strony procesu inwestycyjnego może prowadzić do znacznego zawyżania cen przetargowych lub nieuzasadnionych roszczeń na etapie realizacji. Analiza ryzyka (w tym geotechnicznego) powinna być realizowana na wszystkich etapach procesu inwestycyjnego (rys. 4).

$\mathrm{Na}$ wstępie należy ustalić zakres analizy ryzyka, określić i wskazać przyczyny wystapienia oraz przewidzieć możliwe następstwa. W drugim etapie należy zdefiniować prawdopodobieństwo wystapienia czynników inicjalizujących pojawienie się ryzyka poprzez analizę zagrożeń (geozagrożeń). Można tu wykorzystać różnego rodzaju metody i narzędzia (Siemińska-Lewandowska, 2010)począwszyodmetodindeksowych(korzystających $\mathrm{z}$ doświadczeń odnośnie zaistniałych awarii i katastrof), poprzez metody jakościowe (oceny na podstawie technik macierzowych i rankingowych - metoda często stosowana $\mathrm{z}$ budownictwie podziemnym $\mathrm{z}$ uwagi na trudno porównywalne i losowo zmienne warunki geologiczne), aż po metody ilościowe (oparte na analizach wrażliwości, drzewa decyzyjne czy symulacje probabilistyczne, np. metoda Monte Carlo, dzięki której uzyskuje się wielkość prawdopodobieństwa osiagnięcia zamierzonego kosztu i terminu budowy).

Jak już wykazano powyżej, zagadnienia przyrodnicze (tu budowa geologiczna) nie są w pełni mierzalne i nie mogą być wystarczająco zwymiarowane (Wysokiński, 1995). W ocenie warunków gruntowo-wodnych zawsze stosuje się uproszczenia i różne modele, które obarczone są marginesem błędu (niepewności). Umiejętność szacowania tej niepewności oraz podejmowanie działania w kierunku jej minimalizacji przybliża nas jedynie do rzeczywistości. Nieuprawnione, wręcz błędne, w geotechnice jest podejście zakładające niezmienność warunków i „literalne odczytywanie”

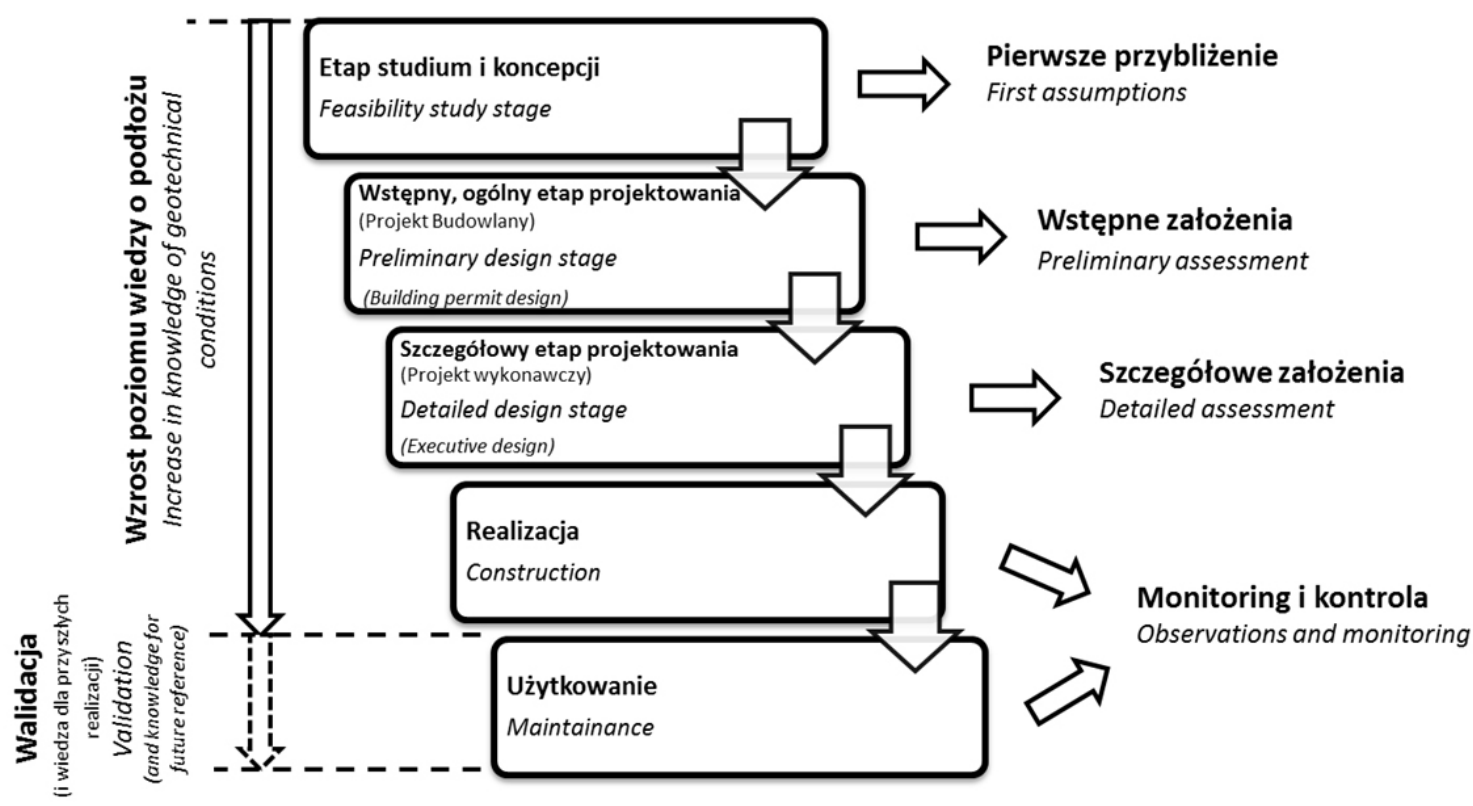

Rys. 4. Schemat szacowania ryzyka geotechnicznego w trybie ciagłym procesu inwestycyjnego (Bogusz i Godlewski, 2017)

Fig. 4. Georisk estimation scheme in continuous mode during the investment process (Bogusz \& Godlewski, 2017) 
informacji podanych np. na przekrojach. Przykładem takiego działania może być kwestia oceny ryzyka kosztowo-terminowego związana $\mathrm{z}$ wyborem optymalnej metody realizacji głębokich wykopów.

Doskonałym przykładem istoty szacowania i zarządzania ryzykiem geotechnicznym jest znana $\mathrm{z}$ realizacji w Warszawie kwestia sposobu realizacji głębokich wykopów w obudowie ze ścian szczelinowych, pełniących funkcję, poza zapewnieniem stateczności wykopu a później przejęcia obciążeń konstrukcyjnych, również odcięcia (w praktyce znacznego ograniczenia) dopływu wód gruntowych do wykopu. Charakterystyczne dla tych realizacji jest poszukiwanie możliwości odcięcia/ograniczenia dopływu wód gruntowych poprzez odpowiednie zagłębienie ścian szczelinowych w utwory izolujace od przenikania wody na wymaganym poziomie (słaboprzepuszczalne). Takie rozwiązanie jest obecnie pożądane, ponieważ skutecznie eliminuje konieczność prowadzenia kłopotliwego (z uwagi na oddziaływania wychodzące poza działkę inwestora, pozwolenia wodnoprawne, problem zrzutu wody, itp.) odwodnienia poza obrysem wykopu. $\mathrm{Na}$ etapie pozyskiwania informacji odnośnie warunków realizacji zapisy podane $\mathrm{w}$ projekcie budowlanym sa często oparte na ograniczonej lub niepełnej ilości danych o położeniu stropu warstw gwarantujących skuteczność takiego rozwiązania, podanej w dokumentacji podstawowej. Poza pozorna oszczędnościa na rozpoznaniu warunków gruntowych jest to też często efekt braku dostępności miejsca (warunki ścisłej zabudowy miejskiej). Na tej podstawie wskazuje się wymagany poziom zagłębienia ścian, bez żadnej dodatkowej analizy możliwych wariantów poszczególnych rozwiązań. Dotyczy to również oszacowania prawdopodobieństwa przebiegu stropu utworów izolujących dopływ wody do wykopu dla najbardziej korzystnego i niekorzystnego wariantu. Takie działanie dałoby wyobrażenie o możliwych zagrożeniach w przypadku wystapienia gorszych z punktu widzenia kosztów realizacji warunków związanych np. z występowaniem lokalnych przegłębień.

$\mathrm{Na}$ terenie Warszawy, w celu spełnienia opisywanej funkcji utworów gwarantujących ograniczenie dopływu wód $\mathrm{w}$ trakcie realizacji wykopu, często konieczne jest osiagnięcie głębokości występowania w podłożu kompleksu iłów mio-plioceńskich formacji poznańskiej, znanych powszechnie jako „iły plioceńskie”, ,iły pstre” czy też „iły trzeciorzędowe”. Utwory te są silnie zmienione diagenetycznie: pierwotna powierzchnia sedymentacyjna jest zdenudowana i porozcinana licznymi wcięciami erozyjnymi, są zaburzone i pofałdowane glacitektonicznie (zwłaszcza w strefie krawędziowej doliny Wisły), charakter tych zmian ma różną skalę (mikro i makro zaburzenia) i zmienność przestrzenną (gwałtowne zmiany stropu na odcinku kilku metrów). $\mathrm{Z}$ tego powodu, jak i z racji swoich właściwości (grunty silnie prekonsolidowane, podatne na zjawiska odprężenia i pęcznienia) stanowią one niekiedy trudne i wymagające podłoże budowlane na terenie Warszawy (Godlewski, 2008).

W tym miejscu należy również odnieść się do pojęcia lokalności w kontekście analizowanej zmienności serii iłów „plioceńskich”. Zakres terminu lokalny w ujęciu przyrodniczym nie mieści się w żadne miary, wszystko zależy od zakresu problemu i skali jego rozpatrywania. Pojęcie lokalności w kontekście zaburzeń w przebiegu stropu warstw izolujących należy rozumieć jako stan charakterystyczny dla danego obszaru i dlatego można je odnosić w sposób uprawniony jedynie do poszczególnych obiektów. Z tego względu termin lokalne pojawiający się w dokumentacjach projektowych często jako słowo-wytrych jest pojęciem nadużywanym, o wielu możliwych płaszczyznach interpretacji, niemniej w przypadku zmienności układu warstw (w tym ich przebiegu) czy zmienności parametrów geotechnicznych należy je rozpatrywać w skali analizowanego problemu, czyli bezpiecznego posadowienia i realizacji obiektu. W praktyce poszukując stropu kompleksu iłów „plioceńskich” jako poziomu zagłębienia ścian szczelinowych, należy ustalać na etapie postępowania przetargowego dokładnie ilości tych elementów konstrukcyjnych $\left(\mathrm{m}^{2}\right)$, ale w wariantach najbardziej optymistycznego i pesymistycznego położenia stropu warstw odcinających. Takie podejście wskazałoby na poziom ryzyka i dałoby podstawę do ustalenia wartości prac z oszacowanym i akceptowalnym (z uwagi na zachowanie konkurencyjności oferty i terminowość realizacji inwestycji) poziomem ryzyka. Racjonalnym podejściem powinno być oszacowanie zakresu prac z określeniem (wycena) spodziewanych możliwych odstępstw. Na przykładzie z praktyki (rys. 5) widoczne są wszystkie dotychczas 

tectura, 17 (3), 27-36. doi: 10.22630/ASPA.2018.17.3.26

omawiane elementy mające wpływ na minimalizację ryzyka geotechnicznego.

$\mathrm{Na}$ etapie projektowym wykonane rozpoznanie (rys. 5a) wskazuje możliwy model podłoża, gdzie w tym przypadku istotnym elementem jest ustalenie przebiegu spoistych gruntów „słaboprzepuszczalnych" pozwalających na odcięcie/ograniczenie dopływu wód gruntowych do wykopu, związanych

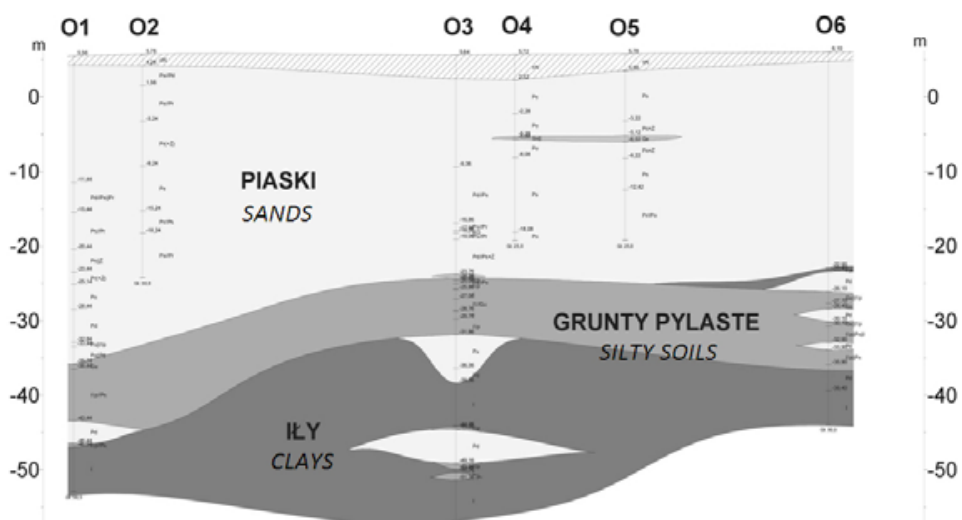

b

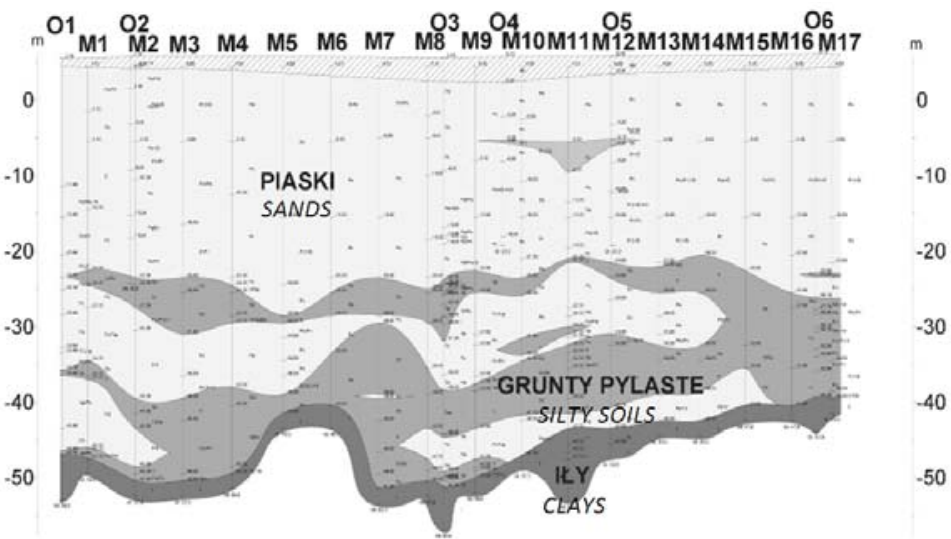

c

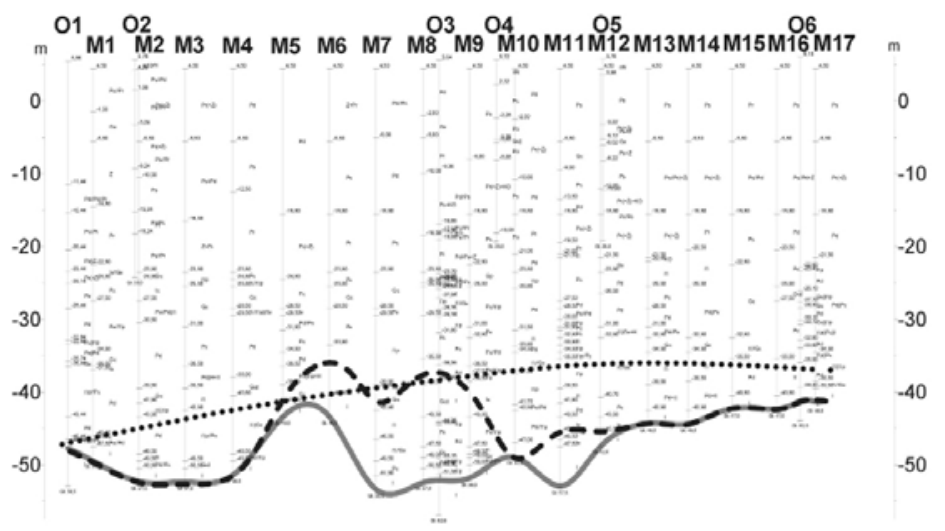

Rys. 5. Przykład modeli podłoża w kolejnych etapach procesu inwestycyjnego: a - rutynowe rozpoznanie na etapie projektowym; b - model opracowany na podstawie profili z metryk ścian szczelinowych; c - porównanie przyjętych rozwiązań odnośnie wymaganego poziomu zagłębienia ścian

Fig. 5. The evolution of ground model at different stages of the investment: a - routine investigation at the design stage; $\mathrm{b}$ - model based on as-built documentation; $\mathrm{c}$ - comparison of required depth depending on design assumptions 
z warstwą piaszczystą o dużej miąższości powyżej. $\mathrm{Na}$ wybranym fragmencie (ok. $100 \mathrm{~m}$ ) wykonano sześć otworów (O1-O6) i jedynie w trzech punktach osiagnnięto strop gruntów spoistych. Na tej podstawie (bez oceny prawdopodobieństwa takiego przebiegu) przyjęto bardzo optymistyczny wariant zagłębienia ścian jako podstawę do kalkulacji oferty. Na etapie realizacji (przekrój uzupełniony o profile $\mathrm{z}$ metryk M1-M17) przyjęty model okazał się dużo bardziej skomplikowany (rys. 5b), co musiało skutkować wydłużeniem ścian (niekiedy nawet o $15 \mathrm{~m}$ ) i roszczeniami.

$\mathrm{Na}$ rysunku $5 \mathrm{c}$, na bazie poprzednich informacji (profili), wrysowano przebieg zagłębienia ścian szczelinowych: projektowany (linia przerywana, krótka), zrealizowany (linia ciagła pogrubiona) i możliwy do bezpiecznego zrealizowania (linia przerywana długa). Dodatkowo w analizowanym przypadku wpływ na samą realizacje miało zbyt ogólne zdefiniowanie warstw pozwalających na odcięcie dopływu wody do wykopu. Częsty opis „....wymagane zagłębienie w iły plioceńskie..." może być interpretowany zbyt dosłownie przez wykonawcę. Wskazany jest bardziej precyzyjny opis cech takiej warstwy (np. możliwe wydzielenia litologiczne czy poziom przepuszczalności wyrażony współczynnikiem filtracji). Analiza przekroju na rysunku 5c wskazuje, że poziom ryzyka nie został określony. W przypadku optymalnego rozwiązania dla analizowanego obiektu zmiana długości ściany szczelinowej nie przekracza $+/-10 \%$. Zatem taki poziom ryzyka powinien być wkalkulowany w cenę wykonawcy. Jednocześnie powyżej tego poziomu Zamawiający mógłby uznawać roszczenie za zasadne.

\section{PODSUMOWANIE}

Prawidłowe szacowanie tego typu zjawisk ukształtowanych całkowicie przyrodniczo (czytaj: losowo) jest możliwe, ale wymaga odpowiedniego podejścia w zakresie identyfikacji i zarządzania ryzykiem. Narzędziem pozwalającym na poprawną identyfikację, a później możliwość minimalizowania jest poprawnie i kompleksowo przeprowadzony etap rozpoznania warunków w podłożu. Poza odpowiednim doborem metod oraz zakresu badań (w tym rozstawu) dochodzi jeszcze problem wiarygodności wyinterpretowanego modelu budowy podłoża z możliwie największym umownym prawdopodobieństwem z rzeczywistością geologiczną. Jedyną możliwością oceny wiarygodności przyjętego modelu jest porównanie przebiegu i rodzaju warstw zaobserwowanych w wyrobiskach badawczych (wkopach, przekopach, szybikach) lub w większej skali w wyrobiskach budowlanych (np. wykopy fundamentowe, tunele) bądź w trakcie prac z nimi związanych (np. na podstawie metryk robót fundamentowych).

Zbyt duże rozbieżności (poza kwestią potencjalnych roszczeń) powinny stać się elementem danych do oceny ryzyka na kolejnych inwestycjach w sasiedztwie, podobnie jak możliwość wykorzystywania informacji $\mathrm{z}$ monitoringu $\mathrm{w}$ myśl pojęcia doświadczenia porównywalnego według Eurokodu 7 (PN-EN 1997-1 i 2:2008).

W dokumentacjach badań podłoża poza prezentacją wyinterpretowanych modeli (najczęściej w formie barwnych przekrojów) brakuje rzetelnej analizy błędów możliwych do popełnienia podczas konstruowania tych modeli oraz wskazania ograniczeń, które wpłynęły na ich obraz. Na marginesie warto wspomnieć, że obecnie wypełnienie wymogów akredytacji w zakresie badań (gruntów) to nie tylko przestrzeganie procedur i wzorcowanie urządzeń, ale również analiza i obliczenia $\mathrm{w}$ zakresie niepewności dla danego oznaczenia. W praktyce często brakuje też jakichkolwiek prób oceny prawdopodobieństwa zgodności prezentowanych modeli z rzeczywistą budową podłoża (np. odnosząc się do sytuacji regionalnej badanego obszaru, danych archiwalnych o terenie, wiedzy i doświadczenia autorów). Można się coraz częściej spotkać z sytuacją odwrotną, w której unika się np. na przekrojach prowadzenia granic przypuszczalnych (linia przerywana), przebieg granic i obszarów „wycina się” nazbyt asekuracyjnie, jednocześnie dając uwagę (poniekąd słuszną) o możliwym innym przebiegu warstw. Są to działania z pozoru poprawne, ale mają charakter „uciekania” od odpowiedzialności dokumentatora, co osłabia pozycję tego zawodu. 
Powszechne podawanie prawdopodobieństwa zgodności modelu geologicznego pozwoliłoby na możliwość identyfikacji i szacowania georyzyka. Następnie zarządzanie ryzykiem i wskazanymi zagrożeniami w procesie inwestycyjnym przyczyniłoby się do bardziej racjonalnego podchodzenia do kwestii realizacji kontraktów na wykonawstwo (mniej sytuacji konfliktowych, roszczeń itp.) oraz wzrostu nakładów na badania podłoża jako narzędzia minimalizującego stwierdzone zagrożenia dla inwestycji w kierunku optymalnej realizacji (taniej i szybciej na wymaganym poziomie bezpieczeństwa i niezawodności).

Wskazany przykład dotyczacy przebiegu stropu warstw izolujących od dopływu wody przy realizacji głębokich wykopów to obecnie najczęstsze źródło konfliktu w relacjach inwestor-wykonawca. Główną przyczyną tego stanu jest brak w dokumentacji przetargowej wskazania na wielkość akceptowalnego poziomu ryzyka geotechnicznego przez zamawiającego (przerzucając praktycznie całe ryzyko na wykonawcę), a jednocześnie brak analiz związanych z szacowaniem georyzyka po stronie wykonawcy (który najczęściej kieruje się zasadą: „wybieram wariant optymistyczny jako najbardziej konkurencyjny, a potem jakoś to będzie").

Powyższe rozważania są efektem coraz częściej obserwowanych sporów i roszczeń wynikających $\mathrm{z}$ braku potrzeby (na poziomie merytorycznym i formalnym) identyfikacji i zarządzania ryzykiem geotechnicznym. Podstawy teoretyczne tego zagadnienia (zarówno w aspekcie przyrodniczym, jak i matematycznym) są znane w literaturze od dawna. Wiedza na temat możliwych błędów i nadinterpretacji przy tworzeniu modeli podłoża to także truizmy znane od lat (przywołana literatura $\mathrm{w}$ tym zakresie to koniec ubiegłego wieku!). Jednocześnie w projektowaniu i realizacji inwestycji postępuje coraz szybszy rozwój metod, technik i narzędzi, to samo dotyczy rozpoznawania i dokumentowania warunków podłoża (nowoczesne sondy, bogate zaplecze laboratoryjne, czy zaawansowane modele i możliwość symulacji w 3D). Mimo to, praktycznie brak jest działań (a może i świadomości) wykorzystujących te narzędzia w kierunku identyfikacji i zarządzania georyzykiem. Wymaga to oczywiście zmian systemowych (w przepisach np. w prawie zamówień publicznych), które pozwolą na egzekwowanie (w celu identyfikacji ryzyka) i odpowiednie finansowanie badań podłoża (w celu minimalizacji ryzyka) w całym procesie inwestycyjnym.

\section{PIŚMIENNICTWO}

Bogusz, W. i Godlewski, T. (2017). Geotechnical interaction in underground space - theory and practice. W C. Madryas et al. (red.). Underground Infrastructure of Urban Areas 4 (strony 19-31). Wrocław: CRS Press, Taylor \& Francis Group.

Brykczyńska, E. i Brykczyński, M. (1974). Geologia przekopu Trasy Łazienkowskiej na tle problematyki zaburzeń osadów trzeciorzędowych i czwartorzędu w Warszawie". Prace Muzeum Ziemi, 199-216. Warszawa.

Godlewski, T. (2008). Ity formacji poznańskiej jako podtoże konstrukcji budowlanych (rozprawa doktorska). Warszawa: Instytut Techniki Budowlanej.

Godlewski, T. (2016). Oddziaływanie w przestrzeni podziemnej obiektów w warunkach infrastruktury miejskiej, przykład z metra warszawskiego. Geoinżynieria: Drogi, Mosty, Tunele, 3 (56), 70-76.

Kowalski, W.C. (1988). Geologia inżynierska. Warszawa: Wydawnictwa Geologiczne.

Kowalski, W.C. (1998). Umowne prawdopodobieństwo zgodności modeli geologicznych z rzeczywistością geologiczna. Przeglad Geologiczny, 46 (1), 95-98.

Mitew-Czajewska, M. (2017). Parametric study of the impact of deep excavation on an existing metro station. W Geotechnical Aspects of Underground Construction in Soft Ground (strony 97-103). London: Taylor \& Francis Group.

PN-EN 1997-1:2008 Eurokod 7: Projektowanie geotechniczne. Część 1: Zasady ogólne.

PN-EN 1997- 2:2008 Eurokod 7: Projektowanie geotechniczne. Część 2: Badania podłoża gruntowego.

Potts, D.M. (2003). Numerical analysis: a virtual dream or practical reality? Géotechnique, 53 (6), 535-573.

Siemińska-Lewandowska, A. (2010). Gtębokie wykopy. Projektowanie $i$ wykonawstwo. Warszawa: Wydawnictwo Komunikacji i Łączności.

Wysokiński, L. (1995). Wiarygodność rozpoznania geotechnicznego w świetle naturalnej zmienności utworów geologicznych, doświadczeń i norm. W Materiały XLI Konferencji w Krynicy. T. 8 (strony 149-158). 


\section{GEOTECHNICAL RISK IN THE DESIGN AND EXECUTION OF DEEP EXCAVATIONS}

\section{ABSTRACT}

Eurocodes assume that proper actions are taken at different stages of an investment process, beginning from preliminary ground investigation, design, execution, and up to maintenance. The main goal is to limit possible risks, including the impact of subsoil variability. First step is to conduct proper geotechnical investigation. The aim of the paper is to revise the problem of subsoil variability, as it is often forgotten in practice, leading to various problems at the construction sites, which later can result in failures, unsubstantiated claims, conflicts, and overdesign of structures. This issue is especially important in the case of underground structures. The role of the scope of an investigation is discussed as one of the contributing factors to mitigate the risk associated with such structures.

Key words: ground investigation, deep excavation, model of subsoil, georisk, risk management 